\title{
Biomass and Carbon Budget of European Forests, 1971 to 1990
}

Kauppi, P.E.

American Association for the Advancement of Science

1992

Kauppi, P.E., Mielikäinen, K. and Kuusela, K. 1992. Biomass and Carbon Budget of European Forests, 1971 to 1990. Science 256: 70-74.

http://hdl.handle.net/1975/296

Downloaded from Helda, University of Helsinki institutional repository.

This is an electronic reprint of the original article.

This reprint may differ from the original in pagination and typographic detail.

Please cite the original version. 


\title{
Biomass and Carbon Budget of European Forests, 1971 to 1990
}

\author{
Pekka E. Kauppi, Kari Mielikäinen, Kullervo Kuusela \\ In severely polluted areas, such as locally in Montshegorsk in northwestern Russia, all trees \\ have died. However, measurements from Austria, Finland, France, Germany, Sweden, and \\ Switzerland show a general increase of forest resources. The fertilization effects of pol- \\ lutants override the adverse effects at least for the time being. Biomass was built up in the \\ 1970 s and 1980 s in European forests. If there has been similar development in other \\ continents, biomass accumulation in nontropical forests can account for a large proportion \\ of the estimated mismatch between sinks and sources of atmospheric carbon dioxide.
}

Forests involve a larger variety of economic, cultural, and social dimensions than perhaps any other natural resource. Forests can be used for industrial and energy production purposes. In addition, they are part of the landscape accessible to people. Forest-dependent fauna and flora represent an enormous heritage of biodiversity. Forests, in comparison to, say, oil reserves, are widely distributed among countries, different regions, owners, and owner groups. Non-owners enjoy environmental benefits from forests and affect management practices by means of publicity and the democratic process. These special characteristics of forests have stimulated discussion and debate on the resource. The discussion in Europe in the 1980s largely focused on one issue, that of the impact of air pollutants on forests.

The authors are with the Finnish Forest Research Institute, Unioninkatu 40 A, SF-00170 Helsinki, Finland.
Air pollutants affect forest ecosystems in many ways. Surveys in Finland, for instance, revealed a decline of epiphytic lichen species over an area of more than $100,000 \mathrm{~km}^{2}$ during the past 25 years (1). Trees themselves can rely on nutrition from deeper soil layers and are less susceptible than the sensitive lichen species to air pollution damage but, as seen in severe cases of decline, trees have their tolerance limits.

Research programs in both North America and Europe have addressed the impacts of air pollutants on ecosystems (2), and forest surveys and growth investigations have been carried out for a long time. Results from all the different studies form an important basis for judgments about the past and future development of forest resources. We analyze and discuss various research results, realizing that any statistical presentation is bound to oversimplify and distort the extreme diversity of what is called "European forest" (3). We focus on the growing stock and growth 

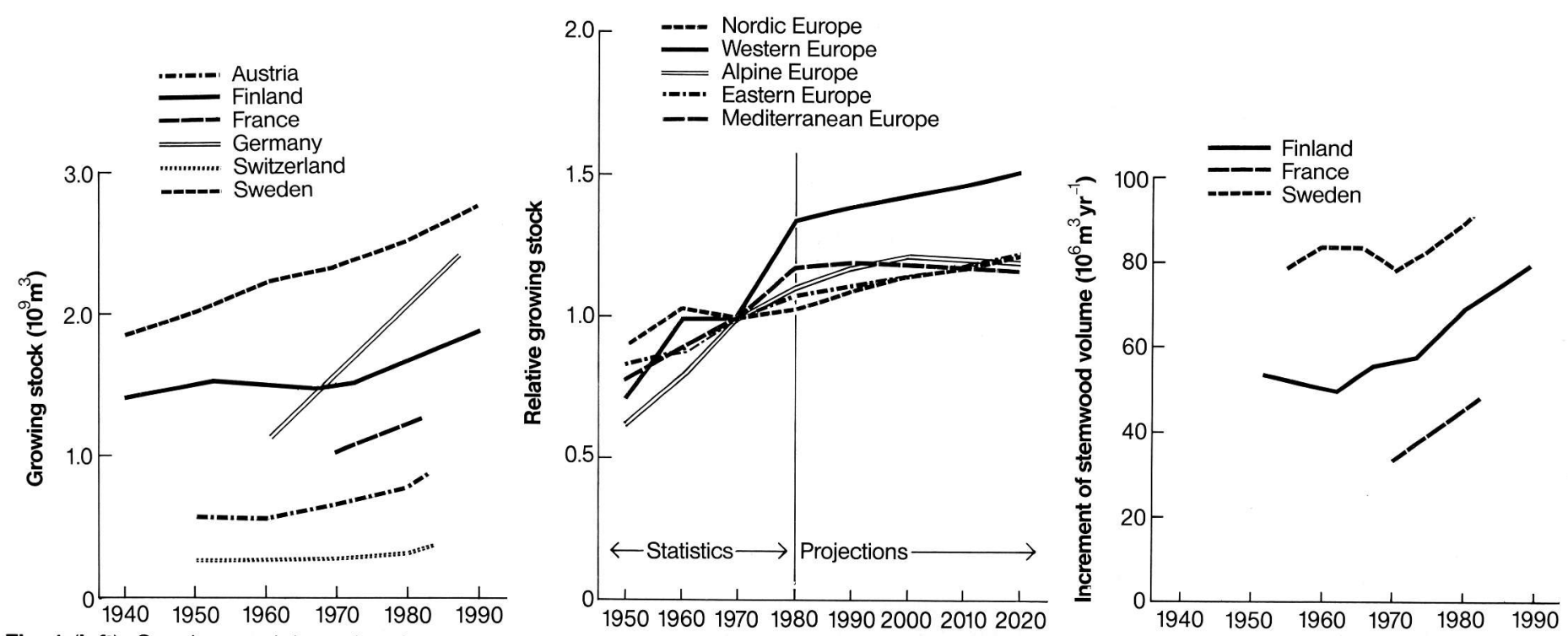

Fig. 1 (left). Growing stock based on forest resource surveys $(5,6)$. The data for France refer to just $75 \%$ of the forest area, and those for Germany of growing stock based on the best available information from different regions in Europe $(3,34)$. The value for 1970 has been adjusted to 10 the area of former West Germany.

Fig. 2 (center). Relative change 1.0 .

Fig. 3 (right). Forest growth in three European countries.

of European forests. The objective is to contribute to the description and understanding of the development of forest resources and forest biomass in the 1970s and 1980s. Reference is made to the impacts of sulfur and nitrogen deposition on forests and to the contribution of European forests to the global carbon budget.

\section{Development of Forest Resources}

Growing stock. Growing stock, the stem volume of living trees, is an important indicator variable of forest resources. We are interested in the average growing stock over large forest regions, preferably over the entire country. The best method of providing objective information on forest resources is to take ground measurements 'rom sample plots located randomly or in a systematic grid (4). The expression "forest resource survey" is used to refer to assessments that are based on statistically representative ground measurements. Additional information based on other methods such as remote sensing, measurements from subjectively located plots, or expert judgment, is useful. However, it cannot replace systematic ground measurements in estimating the true magnitude of forest resources at any given time.

During the past two decades, reports of forest resource surveys have been available from Austria, Finland, France, and Sweden (5). In addition, assessments can be made for the former West Germany and for Switzerland, although earlier surveys in these cases were not based on systematic sampling in the strict sense (6). Growing stock in these countries has increased (Fig. 1). The most rapid increase was reported in Germany, but this might reflect an underestima- tion of the baseline resource of 1961 .

Countries that do not carry out forest resource surveys assess growing stock mainly by combining management plan inventories. They are based on standwise ocular estimates. The United Nations Economic Commission for Europe (ECE) has collected information from all European countries and has also published national projections of growing stock up to 2020 (3). All countries reported an increase of growing stock between 1950 and 1980. According to these statistics, growing stock increased in Europe by $12.3 \%$ between 1971 and 1980 . The increase was projected to continue at a reduced rate (Fig. 2). However, the countries that have carried out forest resource surveys since 1980 did not report a slackening of the trend (Fig. 1). Therefore, we estimate an unchanged development in the 1980 s, yielding a $25 \%$ larger growing stock in 1990 than in 1971.

Forest growth. The increment of stemwood volume (forest growth) is another important indicator of forest resources. Like growing stock it can be measured from forest resource surveys. The technique is slightly more demanding, including remeasurement of permanent sample trees or tree ring analysis of systematically chosen trees. Growth measurements are available only from a few forest resource surveys. The observed trends were similar in Finland, France, and Sweden, indicating that forest growth increased by about $30 \%$ between the early 1970 s and the late 1980s (Fig. 3).

Decline cases. Investigations on severe forest decline are under way, for example, in the vicinity of Montshegorsk smelter, Kola, in northwestern Russia (7). The smelter is located north of the Arctic Cir- cle, yet within a forested landscape about $100 \mathrm{~km}$ south of the Arctic timberline. After establishment of the plant in 1939, the sulfur emissions increased to annual amounts of about 110,000 tons in the 1980s. The emissions contain heavy metals. The area of forest decline surrounding this plant is perhaps the largest in Europe around an individual point source at the present time. Within a radius of $5 \mathrm{~km}$ only dead trees are available for increment sampling and retrospective growth analyses.

Severe decline like that at Montshegorsk is rare. On the basis of country reports to the ECE programs, remote sensing, national surveys, field investigations, and expert reports, we estimate that an upper approximation of the area of severely damaged forests would be $2000 \mathrm{~km}^{2}$ in the former Soviet Union, $1000 \mathrm{~km}^{2}$ in Poland, $1000 \mathrm{~km}^{2}$ in Czechoslovakia, and $1000 \mathrm{~km}^{2}$ in Germany and that in the rest of Europe, less than $3000 \mathrm{~km}^{2}$. Thus, based on this first approximation, cases of severe decline in Europe cover a maximum of $8000 \mathrm{~km}^{2}$, or less than $0.5 \%$ of the forest area, and so do not have much impact on the forest resources of the continent.

Growth at tree and stand level. Tree growth has been studied in many European countries and in many tree species. The investigations have generally indicated a slight increase of tree growth during this century (8). In Germany, present stands were observed to grow faster than the stands of earlier rotations on the same plots. Favorable climate conditions (high temperatures and high precipitation) and the increasing effect of nitrogen deposition have been mentioned as possible causes of this increase (9).

In southern Sweden, Hallbäcken and 
Tamm observed soil acidification in terms of declining $\mathrm{pH}$ between the 1920s and the 1980 s (10). In another study from the same region, stored soil chemistry samples from 29 stands, taken in the 1940s, were compared with recent samples from the same sites (11). Acidification was observed as $\mathrm{pH}$ decline and as a decrease in the levels of sodium, manganese, zinc, calcium, magnesium, and potassium. There was a simultaneous increase in nitrogen availability. Compared to the appropriate reference level, the growth of beech stands increased, yet the growth of oak stands remained stable. The interpretation was that fertilization responses obscured the potential adverse effects of soil acidification.

\section{The Concept of Forest Decline}

The facts about forest resources seemingly contradict the widely held view that European forests are declining. It is important, however, to understand the different objectives and dimensions of forest assessments. It is also important to take a look into the future, as well as into the past. We first elaborate on reasons for the increase of forest resources and then describe pitfalls in the interpretation of forest health surveys, which have contributed to pessimistic views about European forests.

Trends in land use. Afforestation of surplus fields and pastures and the drainage of peatlands, especially in the Nordic countries, increased the area of exploitable closed forests in Europe by $2.5 \%$ between 1970 and 1980 (3). Initially, afforested land is covered by seedlings. Growing stock and stand growth remain low during the early phases of a rotation. The increase of growing stock and forest growth observed in Europe between 1971 and 1990 is almost entirely from stands that were already in place in 1971.

Unexploitable closed forest in Europe occupies about $140,000 \mathrm{~km}^{2}$ or nearly $7 \%$ of total forest and other wooded land (3). An area is classified as unexploitable closed forest as a result of criteria such as physical inaccessibility; legal restriction of commercial felling because of protection, conservation, or biological or recreation functions; and economic criteria (low stand productivity or excessive costs of harvesting or transport). The buildup of wood in unexploitable forests makes only a minor contribution to the observed trends of increase in standing stock and growth.

Universal-global tendencies. Clawson reports that growing stock and timber growth potential in the United States have been "repeatedly and seriously underestimated" (12). An increase of forest resources can be explained by factors such as silvicultural development, favorable climatic conditions, the fertilization effect of additional carbon dioxide in the air (13), and the deposition of plant nutrients, particularly nitrogen. These factors have the potential of increasing both growing stock and forest growth in the manner observed in Europe in the 1970s and 1980s. They have a potential of affecting, on a universal or global level, all areas where deforestation does not override them.

Forest health surveys. International forest health surveys are being carried out by the ECE (14) and by the European Community (EC) (15). The health status of forests has been expressed as the percentage of defoliated and dying trees. In most European countries, more than $15 \%$ of trees were moderately to severely defoliated, defined as having a crown density at least $25 \%$ less than that of the reference tree (14). It has proved feasible to classify defoliation and discoloration in a reproducible manner if there is appropriate training of the field teams, statistically sound sampling, and organized, independent control of the measurement. Trees with defoliated crowns grow less than trees with dense foliage (16). However, problems of interpretation have emerged. First, it has been difficult to provide sufficient training, calibration, and control of the field groups in the large-scale surveys (17); second, stand dynamics involve self-thinning, which contributes to the defoliation of tree crowns.

Self-thinning is linked to stand growth following a simple geometric law: a large tree occupies more space than a small one (18). A high rate of increase in the number of defoliated trees does not always indicate a declining stand but can be a sign of intensive growth. Silvicultural thinning has a direct effect on forest health statistics: the more thinning, the lower the number of defoliated and dying trees (19).

The programs of both the ECE and EC have plans for the near future to measure and assess growth and soil characteristics. They should also consider measuring growing stock. For example, the stemwood vol ume of nondefoliated trees in a region could be a useful forest health indicator, being relatively insensitive to self-thinning dynamics and thinning removals.

\section{Pollution Climate and Forest Responses}

Concentrations and fluxes. Pollutant emissions have changed the chemistry of the atmosphere and affected forests. The $\mathrm{CO}_{2}$ concentration in the air increased by about 9\% between 1971 and 1990. Sulfur and nitrogen emissions in Europe have been as high or higher than those in North America (20). Typical amounts of anthropogenic deposition in European forests vary from 1 to $4 \mathrm{~g}$ of sulfur per square meter and from 0.5 to $2 \mathrm{~g}$ of nitrogen per square meter annually (Fig. 4).

Negative and positive effects. The different, overlapping, and partly opposite effects $r^{\prime}$ pollutants on forests can be analyzed in th same way as the effects of the variation of
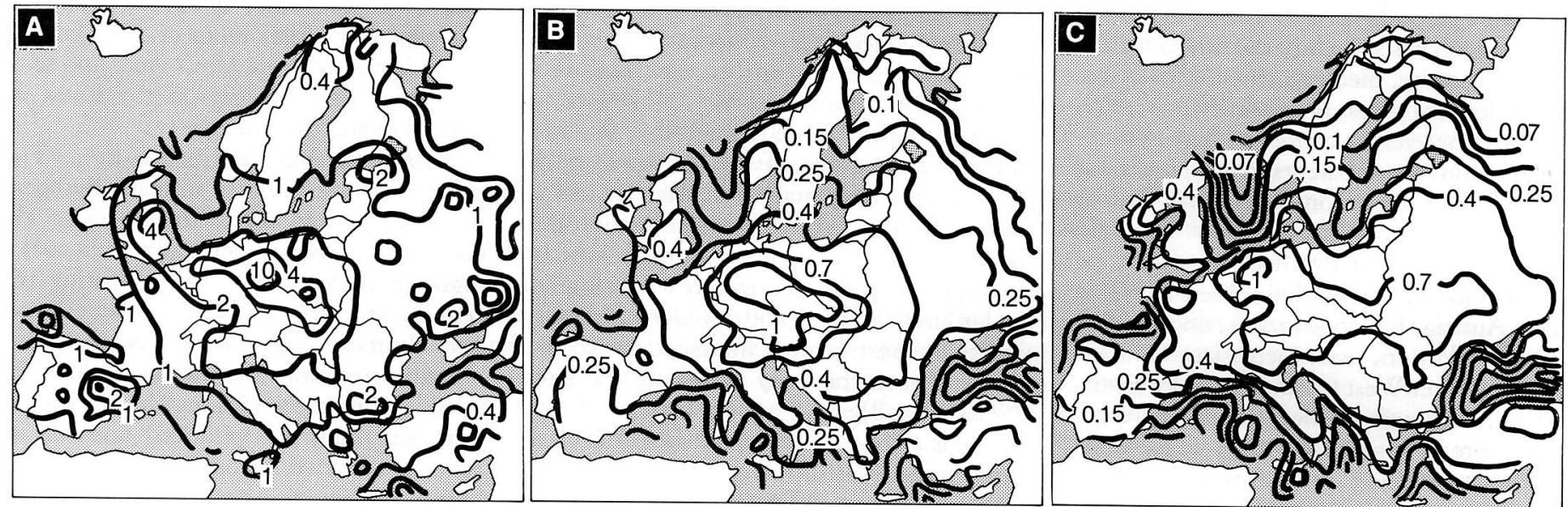

Fig. 4. Total deposition in 1985 of (A) sulfur in grams of sulfur per square meter per year and (B) oxidized and (C) reduced nitrogen in grams of nitrogen per square meter per year [redrawn from (20)]. 
Table 1. Estimating carbon accumulation in the growing stock.

\begin{tabular}{|c|c|c|c|c|c|}
\hline $\begin{array}{c}\text { Base-line } \\
\text { growing } \\
\text { stock, } \\
1971(29) \\
\left(\mathrm{m}^{3}\right)\end{array}$ & $\begin{array}{c}\text { Increase } \\
1971- \\
1990 \\
(\%)\end{array}$ & $\begin{array}{c}\text { Average } \\
\text { increase } \\
1971-1990 \\
\left(\mathrm{~m}^{3} \mathrm{yr}^{-1}\right)\end{array}$ & $\begin{array}{l}\text { Conversion } \\
\text { to dry } \\
\text { weight } \\
(32) \\
\left(\mathrm{kg} \mathrm{m}^{-3}\right)\end{array}$ & $\begin{array}{c}\text { Conversion to } \\
\text { carbon }(32) \\
{[\mathrm{g}(\mathrm{C}) \mathrm{kg}} \\
\left.(\mathrm{dw})^{-1}\right]\end{array}$ & $\begin{array}{l}\text { Annual } \\
\text { buildup of } \\
\text { carbon } \\
\text { (g) }\end{array}$ \\
\hline $20 \times 10^{9}$ & 25 & $250 \times 10^{6}$ & 400 & 500 & $50 \times 10^{12}$ \\
\hline
\end{tabular}

natural environmental factors. Cannell (21) reviews the physiology of wood production and describes pathways for the effects of environmental factors on growth. It is a common perception that air pollutants have either negligible or adverse effects on such plant mechanisms. However, pollutants, like other environmental factors, can have both negative and positive effects on wood production, depending on conditions.

There is convincing evidence that the deposition of sulfur, nitrate, and ammonium has significantly modified plant nutrition and soil chemistry. Moreover, trees have responded to soil chemistry in terms of discoloration symptoms (22). In the long term, these processes can have adverse effects on forest resources.

It is possible, however, that fertilization responses, in particular to nitrogen, play a dominating role in a major part of the European forest area at the present time. A comparison can be made with the effect of applied nitrogen fertilizer. Even in Germany, where nitrogen deposition has been as high as 3 to $5 \mathrm{~g}$ per square meter per year, nitrogen fertilizer application has increased stand growth (23). In Finland it has been calculated that the nitrogen fertilization programs (24) contributed 1 to 2 million cubic meters per year to the growth of Finnish forests in the 1970s and 1980s (25). This is roughly $2 \%$ of the total stemwood growth, which was about 80 million cubic meters per year in 1985 to 1990 .

Growth responds less to deposition nitrogen than to fertilizer nitrogen. Deposition falls onto forest clearings and sparsely stocked areas, not just onto the most responsive stands. Deposition in winter can bypass trees and leach into surface water with the snow melt. Nevertheless, the order of magnitude of nitrogen deposition entering forests in Europe is as high as 0.5 to 2.5 million tons annually (20). This is 50 to 250 times the amount applied in the nitrogen fertilization programs in Finland; such an amount must have an effect on forest resources.

Time horizon. An eventual forest response can change over time. A chemical compound can first enhance and later inhibit stand growth (26). The environment of entire forest regions changes slowly, on a time scale of decades rather than years. It is unlikely that the trend of increase of forest resources, so consistent and forceful in Europe in the 1970s and 1980s, can change in the future within the time scale of 5 to 10 years. However, the long-term development, relevant as the basis for sustainable forestry, is uncertain.

\section{The Carbon Budget}

Mismatch of sources and sinks. Global carbon budgets have been constructed taking into account emissions of $\mathrm{CO}_{2}$ from deforestation and fossil fuel combustion, absorption of $\mathrm{CO}_{2}$ into oceans, and the buildup of $\mathrm{CO}_{2}$ into the atmosphere. Budget calculations have remained incomplete since the estimated annual sinks appeared about 1.2 billion tons of carbon too low (27). It has been assumed that nontropical forests are in equilibrium with the atmosphere, thereby releasing and absorbing equal amounts of $\mathrm{CO}_{2}$ each year. The assumption has been questioned (28) and the above statistics suggest that it is not valid for Europe. We now estimate how these findings narrow the gap in the global carbon budget.

Forest as carbon sink. Assuming a baseline growing stock of 20 billion cubic meters over bark in Europe in 1971 (29), and an increase of $25 \%$ to the year 1990 , we estimate an annual buildup of 250 million cubic meters of stemwood and bark, or 50 million tons of carbon (Table 1). Additional forest biomass has accumulated in branches, roots, foliage, and the organic fraction of forest soils. Assuming a range of 0.4 to 1.1 units of other forest biomass for one unit of accumulated stemwood (30), we estimate an annual accumulation of 70 to 105 million tons of carbon in European forests in the 1970s and 1980s.

In addition, 138 million cubic meters of sawed wood and wood-based panels were used in Europe in 1979-1980. The consumption was 55 million cubic meters in 1913, and 65 million annually between 1949 and 1951 (3). New production of sawed wood and wood-based panels partly replaces old structures and in this case has little or no effect on net $\mathrm{CO}_{2}$ fluxes. Some of the new structures decompose rapidly. We estimate that about 80 million cubic meters per year was stored in new structures, thereby providing an annual sink of 15 million tons of carbon. Paper and board products were located in stores and dumps where decompo-
Table 2. Carbon sinks in European forestry, 1971 to 1990 , in relation to the carbon budget.

\begin{tabular}{lr}
\hline \multicolumn{1}{c}{ Measure } & $\begin{array}{c}\text { Carbon flux } \\
\left(10^{6} \text { ton } \mathrm{C}\right. \\
\left.\mathrm{yr}^{-1}\right)\end{array}$ \\
\hline $\begin{array}{c}\text { Deficit of sinks in the global } \\
\text { carbon budget (27) }\end{array}$ & 1200 \\
$\mathrm{CO}_{2}$ emissions in 1985 in & 2180 \\
Europe (33) & \\
Buildup in Europe & 50 \\
Stemwood and bark & 15 \\
Other forest biomass & $20-55$ \\
Sawed wood and panels & 15 \\
\hline
\end{tabular}

sition is hindered. Statistics are lacking, however, and we omit this carbon sink.

The fluxes can be compared to the release of $\mathrm{CO}_{2}$ from fossil fuels (Table 2). Our data indicate that European forests accumulated 85 to 120 million tons of carbon per year in the 1970s and 1980s; this represents 8 to $10 \%$ of the "missing" flux in the global carbon budget. If global or universal mechanisms play a role in Europe, similar biomass accumulation should have occurred also in other continents. This hypothesis should be carefully tested. A large proportion of the gap in the global carbon budget might be accounted for by proper estimation of biomass accumulation in nontropical forests.

\section{Conclusions and Policy Implications}

Despite air pollutants, forest resources have increased in Europe. It is a drawback that information from repeated surveys is available from an area covering only about one third of the European forests. Uncertainty is greatest regarding the forest resources of the former Soviet Union. However, forest survey results are consistent with the best available information from the remaining area as compiled in ECE statistics. Additional consistent information is available from investigations of growth from individual stands. In summary, we estimate that growing stock and forest growth in Europe increased between 1971 and 1990 by 25 and 30\%, respectively.

This information seemingly contradicts the commonly held view of a forest decline in Europe. There are no descriptions in the literature of a negative impact of air pollutants on growing stock or on growth over large forest areas. A decline of forest resources in Europe is a threat for the future, not a historical fact.

The current trend of increase of growing stock can hardly change within the next 5 to 10 years. Severe climatic perturbations could alter the picture. Thereafter, the favorable development of forest resources is at risk. Sulfur and nitrogen deposition has acidified soil and freshwater, altered the nutrient supply of forests, affected sensitive plant 
species, and contributed to the discoloration and defoliation of trees. Attention should be paid to such early warning signs, bearing in mind the irretrievable value of forest growth potential. Past development, nonetheless, guarantees that during the next 10 to 20 years, wood resources are plentiful and can be allocated among traditional forest industries, eventual novel technologies such as ethanol production (31), and nature protection and conservation purposes.

\section{REFERENCES AND NOTES}

1. M. Kuusinen, K. Mikkola, E.-L. Jukola-Sulonen, in Acidification in Finland, P. Kauppi, P. Anttila, K. Kenttämies, Eds. (Springer-Verlag, Berlin, 1990), pp. 397-420.

2. Acidic Deposition : State of Science and Technology (Superintendent of Documents, Government Printing Office, Washington, DC, 1990), vols. 1-4; The Canadian Long-range Transport of Air Pollutants and Acid Deposition Assessment Report (Environment Canada, Toronto, 1990), parts 1-8; P. Kauppi, P. Anttila, K. Kenttämies, Eds., Acidification in Finland (Springer-Verlag, Berlin, 1990); G. J. Heij and T. Schneider, Eds., Acidification Research in the Netherlands (Elsevier, Amsterdam, 1991); G. Landmann, Ed. French Research into Forest Decline (ENGREF, Nancy, France, 1991).

3. European Timber Trends and Prospects to the Year 2000 and Beyond (United Nations ECE/FAO, Publ E.86.II.E.19, New York, 1986)

4. F. Loetsch, F. Zöhrer, K. E. Haller, Forest Inventory Verlagsgesellschaft, Munich, Germany, 1973), vols. 1 and 2

5. In Austria, Mitt. Forstl. Bundes-Versuchsanst. Wien 154 (1985) and Oesterr. For. Auswertung. 1981-1985; in Finland, K. Kuusela and S. Salminen, Acta For. Fennica 220 (1991) and E. Tomppo and M. Siitonen, Paper Timber 73, 2 (1991); in France, J. C. Deheeger, Rev. For. Fr. (Nancy) 40, 131 (1988); and in Sweden, Statistical Yearbook of Forestry 1991 (National Board of Forestry, Jönköping, Sweden, 1991).

6. In Germany, according to Agrarbericht 1991 (Deutscher Bundestag, Bonn, 1991) the growing stock per unit land area was about $160 \mathrm{~m}^{3} \mathrm{ha}^{-1}$ in 1961 and $300 \mathrm{~m}^{3} \mathrm{ha}^{-1}$ in 1987 . The forest land area in 1987 was $77,500 \mathrm{~km}^{2}$. We assume the same figure for 1961; in Switzerland, Schweizerisches Landesforstinventar, Ergebnisse der Erstaufnahme 1982-1986 (Birmensdorf, Switzerland, 1988).

7. E. Tikkanen and M. Varmola, Eds. Report 373 (Finnish Forest Research Institute, Rovaniemi, 1991).

8. M. Becker, Can. J. For. Res. 19, 1110 (1989); J. L. Innes and E. R. Cook, ibid., p. 1174; H. Spiecker Water, Air, Soil Pollut. 54, 247 (1990/91).

9. G. Kenk and H. Fischer, Environ. Pollut. 54, 199 (1991); G. Kenk, H. Spiecker, G. Diener, Referenzdaten zum Waldwachstum. Summary: Reference Data on Forest Growth, (Projekt Europäisches Forschungszentrum für Massnahmen zur Luftreinhaltung, Freiburg, Germany, 1991).

10. L. Hallbäcken and C. O. Tamm, Scand. J. For. Res. 1, 219 (1986).

11. U. Falkengren-Grerup and H. Eriksson, For. Ecol. Manage. 38, 37 (1990).

12. M. Clawson, Science 204, 1168 (1979).

13. Additional $\mathrm{CO}_{2}$ in the air can stimulate photosynthesis and alleviate drought [R. M. Gifford, Aust. Plant Physiol. 6, 367 (1979)].

14. Forest Damage and Air Pollution. Report of the 1990 Forest Damage Survey in Europe. (UN ECE Convention on Long-Range Transboundary Air Pollution, International Co-operative Programme on Assessment and Monitoring of Air Pollution Effects on Forests, GEMS, Hamburg, 1991).

15. European Community Forest Health Report 1989 (Commission of the European Communities, Di-
rectorate-General for Agriculture, Luxembourg, 1990)

16. P. Nöjd, in (1), pp. 507-522.

17. J. L. Innes, Can. J. For. Res. 18, 560 (1988); E.-L. Jukola-Sulonen, K. Mikkola, M. Salemaa, in (1), pp. 523-560.

18. E. Gorham, Nature 279, 148 (1979)

19. K. Kuusela, The Dynamics of Boreal Coniferous Forests (Gummerus, Jyväskylä, Finland, 1990).

20 A Eliassen, Ö Hov, T Iversen, J Saltbones, D. Simpson, Report 1/88 (Nonwegian Meteorological Institute, Meteorological Synthesizing Centre, Oslo, 1988)

21. M. G. R. Cannel, Scan. J. For. Res. 4, 459 (1989)

22. E.-D. Schulze, Science 244, 776 (1989)

23. G. Kenk and H. Fischer, Environ. Pollut. 54, 199 (1991): H. Spiecker, Fert. Res. 27, 87 (1991).

24. E. Mälkönen, J. Derome, M. Kukkola, in (1), pp. 325-347; Yearbook of Forest Statistics (Finnish Forest Research Institute, Helsinki, 1990), p. 760.

25. Forest-2000 Program (Finnish Ministry of Agriculture and Forestry, Helsinki, 1984).

26. N. van Breemen and J. M. Verstraten, in Acidification Research in the Netherlands, G. J. Heij and T. Schneider, Eds. (Elsevier, Amsterdam, 1991), pp. 289-352; G. M. J. Mohren, ibid., pp.
$387-464$

27. R. P. Detwiler and C. A. S. Hall, Science 239, 42 (1988).

28. R. A. Sedjo, Science 241, 1737 (1988), C. S Binkley, ibid. 243, 991 (1989); P. Kauppi and M. Posch, ibid., p. 1535, R. A. Sedjo, ibid. 244, 631 (1989).

29. In 1980, the growing stock in Europe excluding the former Soviet Union was 15.9 billion cubic meters (overbark) according to The Forest Resources of the ECE region (Europe, the USSR, and North America) (UN ECE/FAO, ECE/TIM/27, Geneva, Switzerland, 1985)

30. S. Brown and A. E. Lugo, Science 223, 1290 (1984).

31. L. R. Lynd, J. H. Cushman, R. J. Nichols, C. E. Wyman, ibid. 251, 1318 (1991)

32. P. Hakkila, Utilization of Residual Forest Biomass (Springer-Verlag, Berlin, 1989).

33. Intergovernmental Panel on Climate Change. Energy and Industry Subgroup Report (U.S. Environmental Protection Agency, Washington, DC, 1991)

34. We thank N. van Breemen, G. Landmann, S. Linder, and P. Nöjd for comments, and M. S. Jarvis for editing. 